\title{
CHARACTERISTICS OF PATIENTS WITH TYPE 2 DIABETES MELLITUS AT SURABAYA HAJI GENERAL HOSPITAL
}

\author{
Ismianti Lifia Bestari \\ Epidemiology Department, Faculty of Public Health, Airlangga University, Surabaya, Indonesia \\ Correspondence Address: Ismianti Lifia Bestari \\ Email: ismianti.lifia.bestari-2015@fkm.unair.ac.id
}

\begin{abstract}
Diabetes mellitus is a chronic disease due to impaired blood glucose levels. Type 2 diabetes mellitus dominantly causes most deaths in the world. The number of patients with type 2 diabetes mellitus (DM) was ranked the second highest at the Surabaya Haji General Hospital. Purpose: This study described characteristics of patients with type $2 \mathrm{DM}$ at the Surabaya Haji General Hospital. Methods: This study was descriptive and used a cross-sectional research design. This study's population were patients with type 2 DM who visited Diabetes Unit at Surabaya Haji General Hospital. This study was conducted in the Diabetes Unit at the Surabaya Haji General Hospital by involving 114 respondents as the samples. These respondents were interviewed using questionnaires from 11 March to 11 April 2019. The study's variables were patients' characteristics including age, gender, family history, and disease duration. Data were analyzed using a univariate analysis with a frequency table. Results: Almost all of patients with type $2 \mathrm{DM}$ at Surabaya Haji General Hospital were aged $\geq 40$ years $(94.7 \%)$ and female $(71.9 \%)$. The majority of patients had a family medical history of type 2 diabetes mellitus disease $(60.5 \%)$ and long disease duration of $>5$ years $(5 ., 4 \%)$. Conclusion: Almost patients with type 2 DM in Surabaya Haji General Hospital were elderly who had a family medical history of diabetes mellitus and had suffered from type 2 diabetes mellitus for $>5$ years.
\end{abstract}

Keywords: diabetes mellitus, characteristics, hospital, descriptions.

\begin{abstract}
ABSTRAK
Diabetes melitus merupakan penyakit kronis yang disebabkan oleh gangguan kadar glukosa darah. Diabetes melitus tipe 2 menyebabkan kematian tertinggi di dunia. Jumlah pasien diabetes melitus tipe 2 menempati urutan kedua tertinggi di RSU Haji Surabaya. Tujuan: Penelitian ini menggambarkan karakteristik penderita diabetes melitus tipe 2 di RSU Haji Surabaya. Metode: Penelitian ini merupakan penelitian deskriptif. Desain penelitian yang digunakan yaitu studi potong lintang. Populasi dalam penelitian ini adalah seluruh penderita diabetes melitus tipe 2 yang berkunjung di Poli Diabetes RSU Haji Surabaya. Besar sampel yang didapatkan sebanyak 114 responden yang diwawancara menggunakan kuesioner mulai 11 Maret - 11 April 2019. Variabel penelitian ini adalah karakteristik penderita meliputi usia, jenis kelamin, riwayat keluarga, dan lama menderita penyakit tersebut. Analisis data penelitian menggunakan analisis univariat dengan menggunakan tabel frekuensi. Hasil: Hampir seluruh penderita diabetes melitus tipe 2 di RSU Haji Surabaya berusia $\geq 40$ tahun (94,7\%) dan berjenis kelamin perempuan (71,9\%). Mayoritas penderita mempunyai riwayat keluarga (60,5\%) dan lama menderita $>5$ tahun (54,4\%). Kesimpulan: Hampir seluruh penderita diabetes melitus tipe 2 di RSU Haji Surabaya adalah lansia, berjenis kelamin perempuan, memiliki riwayat keluarga dan lama menderita $>5$ tahun.
\end{abstract}

Kata kunci: diabetes melitus, karakteristik, rumah sakit, gambaran.

\section{INTRODUCTION}

One of the diseases that becomes a major global concern is non-communicable diseases (NCD). Non-Communicable Diseases (NCD) increase mortalities worldwide. An increasing noncommunicable disease is Diabetes Mellitus (DM). Diabetes mellitus is a chronic disease due to insufficient insulin produced by the pancreas. Insulin itself is a hormone that regulates blood sugar or glucose (WHO, 2016).

According to the 8th edition International Diabetes Federation in 2017, there were around 424.9 million people with DM worldwide, and the number of deaths due to DM was around 4 million. 
The prevalence of mortalities has also been predicted to increase from $8.8 \%$ in 2017 to $9.9 \%$ in 2045 . While the number of people with DM predictably will increase to 628.6 million (IDF, 2017). Diabetes mellitus was ranked 7 th most common cause of deaths globally in 2016 at 1.6 million deaths in total. Deaths due to diabetes mellitus increased from 1 million in 2000 to 1.6 million in 2016 (WHO, 2016). Based on the health statistics of the World Health Organization (WHO, 2018), Indonesia had the highest mortalities due to diabetes at $26.4 \%$ of 261.1 million total population in 2016.

East Java province was ranked 6th out of 10 Indonesian provinces for the highest diabetes prevalence of $2.1 \%$ which was higher than the average national DM prevalence of $1.5 \%$ (East Java Provincial Health Office, 2016)). In East Java, as the number of patients with DM increased from 275,462 in 2007 to 605,974 patients in 2013. Surabaya city had the highest number of patients with DM which increased from 102,599 in 2017 to 115,460 in 2018 (Surabaya District Health Office, 2018). Base on the blood test, the percentage of people with DM aged greater than or equal to 15 years was $6.9 \%$ in 2013 and increased to $10.9 \%$ in 2018 . Diabetes mellitus mostly occurs to people over 40 years old, and $1.8 \%$ of patients with DM was female (RISKESDAS, 2018).

Most adults suffer from type 2 diabetes mellitus, but the incidence of type 2 diabetes might possibly occur to children and adolescents. The proportion of people with type $2 \mathrm{DM}$ at $90 \%$ was greater than other types of diabetes (IDF, 2015). The high DM incidence is caused by two factors: patient factor and risk factor. Patient behavior is a controllable factor. While, uncontrollable risk factors include race and ethnicity, age, sex, family medical history of diabetes mellitus, history of giving birth to a baby weighed more than 4000 grams, and a history of low birth weight at less than 2500 grams. Meanwhile, controllable risk factors involve unhealthy living behaviors, obesity, lack of physical activity, impaired blood glucose levels, and smoking (Indonesian Ministry of Health, 2014).

The Surabaya Haji General Hospital is a type-B public hospital owned by East Java Provincial Government. The number of diabetes patients who undergo outpatient and inpatient care at the Surabaya Haji General Hospital is quite high. Based on the 2017 medical record data,there were 1349 patients with DM in the inpatient unit. Whereas, the outpatient unit had the highest reported DM patients as many as 11,689 patients. In 2017, there was an increase of 11,689 to 16,271 outpatients with DM in 2018. It shows that the number of patients with type 2 DM from 2017 to 2018 increased by 4,582 . From the issues above, this study aimed to describe characteristics of patients with type 2 DM at Haji General Hospital.

\section{METHODS}

This study was descriptive and used a cross-sectional research design. The study's population was all patients with type $2 \mathrm{DM}$ who visited the Diabetes Unit at Haji General Hospital Surabaya. A total of 114 patients were selected using accidental sampling. These patients who met the inclusion criteria and were willing to participate were taken as research respondents.

This study was carried out at the Diabetes Unit of Surabaya Haji General Hospital from March $11^{\text {th }}$ to April $11^{\text {th }}$, 2019. The variables examined were patient characteristics including age, sex, family medical history of DM, and disease duration. Data were collected through interview questionnaires and then were analyzed using a univariate analysis which results were displayed in data frequency tables. This study has obtained an ethical clearance from Health research ethics committee of RSU Haji Surabaya the ethics approval number 073 / 14 / KOM ETIK / 2019. 


\section{RESULT}

Frequency distribution of patient characteristics by age

Table 1. Distribution of Patient

Characteristics by Age.

\begin{tabular}{lcc}
\hline \multicolumn{1}{c}{ Age } & Total & $\begin{array}{c}\text { Percentage } \\
(\boldsymbol{\%})\end{array}$ \\
\hline$<40$ years & 6 & 5.3 \\
$\geq 40$ years & 108 & 94.7 \\
\hline Total & 114 & 100 \\
\hline
\end{tabular}

Table 1 shows that most of the patients were in the age group of more than or equal to 40 years $(94.7 \%)$. Only few were aged than 40 years $(5.3 \%)$.

\section{Frequency distribution of patient characteristics by gender}

Table 2 illustrates that there were more female patients $(71.9 \%)$ compared to male ones $(28.1 \%)$.

Table 2. Distribution of Patient Characteristics by Gender.

\begin{tabular}{lcc}
\hline Gender & Total & $\begin{array}{c}\text { Percentage } \\
(\boldsymbol{\%})\end{array}$ \\
\hline Male & 32 & 28.1 \\
Female & 82 & 71.9 \\
\hline Total & 114 & 100 \\
\hline
\end{tabular}

Frequency distribution of patient characteristics by family medical history

This study finds most of the patients had a family medical history of diabetes $(60.5 \%)$.

Table 3. Frequency Distribution of Patient Characteristics by Family History.

\begin{tabular}{lcc}
\hline Family History & Total & $\begin{array}{c}\text { Percentage } \\
(\%)\end{array}$ \\
\hline Yes & 69 & 60.5 \\
No & 45 & 39.5 \\
\hline Total & 114 & 100 \\
\hline
\end{tabular}

Frequency distribution of patient characteristics by disease duration

Table 4. Characteristic Frequency

Distribution of Patients with

Type-2 DM by Disease Duration.

\begin{tabular}{lcc}
\hline \multicolumn{1}{c}{$\begin{array}{c}\text { Disease } \\
\text { Duration }\end{array}$} & Total & $\begin{array}{c}\text { Percentage } \\
(\boldsymbol{\%})\end{array}$ \\
\hline$\leq 5$ years & 52 & 45.6 \\
$>5$ years & 62 & 54.4 \\
\hline Total & 23 & 100 \\
\hline
\end{tabular}

Table 4 shows that more than a half of patients had suffered from type $2 \mathrm{DM}$ for more than 5 years (54.4), while another half suffered from the disease for less than or equal to 5 years $(45.6 \%)$.

\section{DISCUSSION}

\section{Respondents' Age}

In this study, the majority of the respondents who suffered from type $2 \mathrm{DM}$ were over 40 years old. This is consistent with from the data published by the Surabaya District Health Office in 2018 which reported people with type $2 \mathrm{DM}$ were mostly over 40 years old (Surabaya City Health Office, 2018). Previous research conducted by Akhsyari (2016) supports this finding by stating that the age group of more than or equal to 40 years was the common stage where people mostly suffer from diabetes. According to Amu (2014), the majority of people with type $2 \mathrm{DM}$ are over 45 years old. People in the age group of more than 45 years have more risk of suffering from type 2 DM (Amira, et al.c 2013). Research conducted by Hakim (2018) states that people with type 2 DM were mostly over 41 years old. Older ages could be at risk because physiological performance at the ages will decrease and cannot control the body's function optimally, thereby decreasing insulin resistance that leads to high blood glucose levels (Jelantik and Haryati, 2014).

Another study conducted by Nakajima, et al. (2017) proved similar finding. Further, Iroth, et al. (2013) have 
found that the age group of over or equal to 45 years had a risk of 0.342 times greater risk of suffering type $2 \mathrm{DM}$ compared to that under 45 years. Nuraisyah (2017) also finds similar result in which the majority of people with type $2 \mathrm{DM}$ were aged over 45 years $(58.5 \%)$. The same thing goes in the studies conducted by Azhara and Kresnowati, (2014), as well as Susanti (2019). Genetic factor in aging contributes to type $2 \mathrm{DM}$ incidence. The olde people are, the greater their risk of suffering from diabetes due to unhealthy lifestyles (Aregbesola, et al. 2017).

\section{Respondents' Gender}

The results of this study indicate that the majority of female respondents suffered from type 2 DM. Coherently, the Surabaya District Health Office in 2018 stated that type 2 DM mostly occur in women than men (Surabaya City Health Office, 2018). Similarly, Chaidir, et al. (2017) and Prasetyani and Apriani (2017) discovered similar finding. Further, Rahayu, et al. (2018)state that $79.4 \%$ of patients with type $2 \mathrm{DM}$ were female. Research conducted by Kistianita, Yunus, and Gayatri (2018) mentions $59.1 \%$ of their respondents with type 2 diabetes mellitus were female. Research conducted by Herdianti (2017) finds that women were 2.35 times more likely to suffer from type $2 \mathrm{DM}$ compared to men. Differences in body fat composition and sex hormone levels may be the reasons on why women have more potential to suffer from DM than men (Isnaini and Ratnasari, 2018).

Furthermore, women are more sensitive to social contexts such as education, income, and employment as an increased risk of diabetes in the (KautzkyWiller, et al.c 2016). Previous studies conducted by Hestiana, (2017) and Aisyah, et al. (2018) have found that the number of females with type 2 DM was more than that of men. Research conducted by Yuliani, et al. (2015) shows most people with type 2 $\mathrm{DM}$ were women. This finding is also similar to the research conducted by
Wardani and Isfandiari (2014) and Dyah, et al. (2014). The incidence of DM is more common in women because they are more prone to obesity due to the hormone estrogen. Obesity is a risk factor for DM due to unhealthy lifestyle (Janitra and Sandika, 2018).

Several studies mention that most women with low quality of life suffered from type 2 DM (Wahyuni, et al. (2014); Liuw, et al (2017). Research conducted by Yosmar, et al. (2018) discovers that women had a higher risk of suffering from DM compared to men. Women with a history of gestational diabetes will be more at risk of suffering from type $2 \mathrm{DM}$ if they do not practice a healthy lifestyle Harreiter and Kautzky-Willer (2018). However, research conducted by (Aregbesola, et al. 2017) opposes this result by saying the majority of men suffered from DM due to lack of physical activity, excessive alcohol consumption, and smoking habits. Excessive and unhealthy food consumption and lack of physical activity will lead to greater risk of suffering from type $2 \mathrm{DM}$, especially among people who are overweight and have a family medical history of DM.

Another study argues that there was no significant difference in risk of type 2 DM in both women and men (Seghieri, et al. 2016). Regardless gender, DM can depend on the management of individual self-care. Harreiter and Kautzky-Willer (2018) mention the worse the self-care, the more risk people suffer form type 2 DM. It is in line with the fact that genetic, lifestyle, and other factors contribute to the rapid increase in the incidence of type $2 \mathrm{DM}(\mathrm{Wu}$, et al. 2014).

\section{Characteristics of patients with type 2 diabetes mellitus by family medical history}

Indicated from the results, the majority of people with type $2 \mathrm{DM}$ at the Surabaya Haji General Hospital ever had a family medical history of diabetes. In the same way, research conducted by Amu 
(2014) shows $84.2 \%$ of DM patients had a family history of diabetes mellitus. Similarly, Kistianita, et al. (2018) found that a family history of diabetes mellitus contributed 12.5 times greater to DM incidences. Some other studies further elaborate that people with DM mostly had a family medical history of diabetes (Mamangkey, Kapantow, \& Ratag, 2014; Zahari, Yunivita, \& Martha, 2017; Susanti, 2019). Those with a family medical history of diabetes were more likely to suffer from DM (Ethics \& Monalisa, 2016).

Furthermore, abnormal blood glucose levels occur to most DM people who have a family history of diabetes(Rudi \& Kwureh, 2017) . Research conducted by Prabowo and Hastuti (2015) finds that $85.9 \%$ of people with DM had a family medical history of diabetes.

Some previous studies further elaborate that most people with type $2 \mathrm{DM}$ were affected by a family medical history of diabetes and environmental factors (Begic, Arnautovic, \& Masic, 2016; Palimbunga, Rataq, \& Kaunang, 2017). Further, Wardiah and Emilia (2018) find peoplewith a family medical history of diabetes would have 3,264 times risk of suffering from DM compared to those without a family history. Another study states people with such family medical history would be 10,938 times more likely to suffer from type $2 \mathrm{DM}$. Despite genetic factors, the prevalence of diabetes increases in children whose parents suffer from diabetes and in groups of certain races (Isnaini and Ratnasari, 2018).

\section{Characteristics of patients with type 2 diabetes mellitus by disease duration}

Most patients participating in this study had suffered from type 2 DM for more than 5 years. This is in line with research conducted at the Dr. Zainoel Abidin District General Hospital, Banda Aceh. The research finds $63.2 \%$ of people with type 2 DM had diabetes for more than 5 years (Sidiq \& Nurleli, 2015). Restada's research (2016) further states that most people with DM had disease duration of 5-10 years.
Some studies discover most people had suffered from DM for more than 5 years (Feliasari's research, 2014; Permana, 2017; Prasetyani \& Apriani, 2017; Tsalissavrina, Tritisari, Handayani, \& Kusumastuty, 2018; Winta, Setiyorini, \& Wulandari, 2018; Ernianti, Martini, Udiyono, \& Saraswati, 2018; Jing et al., 2018; Made et al., 2019). This finding is further supported by Aprilyasari (2015) who finds $95 \%$ of people had from the disease for more than 5 years.

Several studies even find DM duration of more than 5 years could lead to cognitive impairment Meloh, Pandelaki, \& Sugeng (2015); Nurmaguphita \& Sugiyanto (2018). Risk of cognitive decline is greater in people with longer diabetes duration (Nuchalida, 2015). Furthermore, Suyanto (2016) mentions that sufferers had a high risk ofcomplications due to prolonged diabetes duration. Functional capacity, psychological, level of health, and level of welfare of patients can be affected by diabetes duration. Microvascular and macrovascular complications will be experienced by patients for a long time and then will cause physiological changes when blood glucose levels are high (Wahyuni, et al. 2014). The quality of life will be affected by diabetes duration as well. Good management of diabetes self-care will maintain a better quality of life (Siwiutami, 2017). The duration of diabetes mellitus depends on how a person can control their blood sugar levels because this disease cannot be cured, but controllable in a lifetime.

\section{CONCLUSION}

It can be concluded that patients with type $2 \mathrm{DM}$ at the Surabaya Hajj General Hospital were mostly over 40 years old or elderly. Most of them were female and had a family medical history of diabetes and had suffered from the disease for more than 5 years.

It is important to takeprevention measures and self-care such as routine blood sugar control, healthy diet patterns, 
and regular physical activity. Thus, the disease will not cause further complications.

\section{REFERENCE}

Aisyah, S., Hasneli, Y. and Sabrian, F. (2018) 'Hubungan antara Dukungan Keluarga dengan Kontrol Gula Darah dan Olahraga Pada Penderita Diabetes Melitus', Jurnal Online Mahasiswa, 5(2), pp. 211-221.

Akhsyari, F. Z. (2016) Karakteristik Pasien Diabetes Mellitus di RSUD $d r$. Soehadi Prijonegoro Sragen Tahun 2015.

Amira, N., Pandelaki, K. and Palar, S. (2013) 'Hubungan Tekanan Darah Dan Lama Menderita Diabetes Dengan Laju Filtrasi Glomerulus Pada Subjek', pp. 0-6. doi: 10.1128/AEM.02614-14.

Amu, Y. (2014) 'Faktor Resiko Kejadian Diabetes Melitus Tipe II di RSUD. Prof. Dr.Hi.Aloei Saboe Kota Gorontalo'.

Aprilyasari, R. W. (2015) 'Hubungan Lama Menderita DM dengan Perilaku Perawatan Kaki secara Mandiri untuk Mencegah Ulkus Diabetikum', Jurnal Keperawatan dan Kesehatan Masyarakat, 2(3), pp. 29-35. doi: 10.31596/jcu.v2i3.61

Aregbesola, A. et al. (2017) 'Gender Difference in Type 2 Diabetes and The Role of Body Iron Stores', Annals of Clinical Biochemistry, 54(1), pp. 113-120. doi: $10.1177 / 0004563216646397$.

Azhara, N. and Kresnowati, L. (2014) 'Faktor Risiko Diabetes Melitus Tipe 2 Di Wilayah Kerja Puskesmas Kedungundu Kota Semarang Tahun 2014', Fakultas Kesehatan Udinus.

Begic, E., Arnautovic, A. and Masic, I. (2016) 'Assessment of Risk Factors for Diabetes Mellitus Type 2', Materia Socio Medica, 28(3), p. 187. 10.5455/msm.2016.28.187-190.

Chaidir, R., Wahyuni, A. S. and Furkhani, D. W. (2017) 'Hubungan Self Care Dengan Kualitas Hidup Pasien Diabetes Melitus', Jurnal Endurance, 2(2), p. 132. doi: 10.22216/jen.v2i2.1357.

Dyah, R. I., Wahyono, D. and Handayani, T. M. (2014) 'Analisis Biaya Terapi Pasien Diabetes Melitus Rawat Inap', Jurnal Manajemen dan Pelayanan Farmasi, 4(1), pp. 5562.

Ernianti, D. et al. (2018) 'Gambaran Kualitas Hidup Penderita Diabetes Melituspada Anggota Dan Non Anggota Komunitas Diabetes Di Puskesmas Ngrambe', Jurnal Kesehatan Masyarakat (e-Journal), 6(1), pp. 215-224.

Etika, A. N. and Monalisa, V. (2016) 'Riwayat Penyakit Keluarga dengan Kejadian Diabetes Mellitus', Jornal care, 4(1), pp. 34-41.

Feliasari, A. (2014) Profil Penderita Diabetes Melitus Tipe 2 dengan Terapi Insulin di Poli Rawat Jalan RSUD Dr. Soedarso Pontianak.

Hakim, D. L. (2018) Hubungan Tingkat Sosial Ekonomi: Pendidikan, Penghasilan, dan Fasilitas dengan Pencegahan Komplikasi Kronis pada Penyandang Diabetes Melitus Tipe 2 di Surakarta.

Harreiter, J. and Kautzky-Willer, A. (2018) 'Sex and gender differences in prevention of type 2 diabetes', Frontiers in Endocrinology, 9(MAY), pp. 1-15. doi: 10.3389/fendo.2018.00220.

Herdianti (2017) 'Determinan Kualitas Hidup Penderita DM Tipe 2 di RSUD Ajjappange', Journal Endurance, 2(1), pp. 74-80. doi:10.22216/jen.v2i1.1662

Hestiana, D. W. (2017) 'Faktor-Faktor yang Berhubungan dengan Kepatuhan dalam Pengelolaan Diet pada Pasien Rawat Jalan DIabetes Mellitus Tipe 2 di Kota Semarang', Journal of 
Health Education, 2(2), pp. 138145. doi: 10.15294/jhe.v2i2.14448

IDF (2015) 'IDF Diabetes Atlas Seventh Edition 2015', Journal of Chemical Information and Modeling. doi: 10.1017/CBO9781107415324.004.

IDF (2017) 'IDF Diabetes Atlas Eighth Edition 2017'.

Iroth, G. S. N., Kandou, G. D. and Malonda, N. S. H. (2013) 'Hubungan Antara Umur Dan Pola Makan Dengan Kejadian Diabetes Mellitus Tipe 2 Pada Pasien Rawat Jalan Di Wilayah Kerja Puskesmas Di Sulawesi Utara', Media Kesehatan, 9(3), pp.1-8.

Isabella, M., Kapantow, N. H. and Ratag, B. T. (2014) 'Hubungan antara Tingkat Pendidikan da Riwayat Keluarga Menderita DM dengan Kejadian DM Tipe 2 pad Pasien Rawat Jalan di Poliklinik Penyakit Dalam BLU Prof. Dr. R. D. Kandou Manado'.

Isnaini, N. and Ratnasari (2018) 'Faktor Risiko Mempengaruhi Kejadian Diabetes Mellitus Tipe Dua', Jurnal Kebidanan dan Keperawatan Aisyiyah, 14(1), pp.59-68. doi:10.31101/jkk.550

Janitra, F. E. and Sandika, D. (2018) 'Hubungan Kontrol Glukosa Darah dengan Penurunan Vaskularisasi Perifer pada Pasien Diabetes Mellitus', Jurnal Penelitian dan Pemikiran Ilmiah Keperawatan, 4(1), pp. 18-22. doi: 10.30659/nurscope.4.1.18-22

Jelantik, I. G. M. G. and Haryati, E. (2014) 'Hubungan Faktor Risiko Umur, Jenis Kelamin, Kegemukan dan Hipertensi dengan Kejadian Diabetes Melitus Tipe II di Wilayah Kerja Puskesmas Mataram', Media Bina Ilmiah, 8(1), pp. 39-44.

Jing, X. et al. (2018) 'Related Factors of Quality of Life of Type 2 Diabetes Patients: A Systematic Review and Meta-Analysis', Health and Quality of Life Outcomes. Health and Quality of Life Outcomes, 16(1), pp. 1-14. doi: 10.1186/s12955-0181021-9.

Kautzky-Willer, A., Harreiter, J. and Pacini, G. (2016) 'Sex and Gender Differences in Risk, Pathophysiology and Complications of Type 2 Diabetes Mellitus', Endocrine Reviews, 37(3), pp. 278316. doi: 10.1210/er.2015-1137.

Kistianita, A. N., Yunus, M. and Gayatri, R. W. (2018) 'Analisis Faktor Risiko Diabetes Mellitus Tipe 2 Pada Usia Produktif Dengan Pendekatan Who Stepwise Step 1 (Core / Inti) di Puskesmas Kendalkerep Kota Malang', Preventia: The Indonesian J of Public Health, 3(1), pp. 1-14.

Liuw, F. F., Kandou, G. D. and Malonda, N. S. H. (2017) 'Hubungan antara Jenis Kelamin dan Diabetes Melitus Tipe 2 dengan Kualitas Hidup pada Penduduk di Kelurahan Kolongan Kecamatan Tomohon Tengah Kota Tomohon', Media Kesehatan, 9(3), pp. 1-7.

Made, N. et al. (2019) 'Lama Menderita Diabetes Melitus Tipe 2 terhadap jarak yang ditempuh selama Six Minute Walk Test', Syifa' MEDIKA: Jurnal Kedokteran dan Kesehatan, 9(2), 65-69.

Meloh, M. L., Pandelaki, K. and Sugeng, C. (2015) 'Hubungan Kadar Gula Darah Tidak Terkontrol dan Lama Menderita Diabetes melitus dengan Fungsi Kognitif Pada Subyek diabete Melitus Tipe 2', Jurnal EClinic, 3(1), pp. 321-327. doi: 10.2118/62580-PA.

Nakajima, K., Suwa, K. and Toyama, K. (2017) 'Age-Dependent Changes in the Association Between Sleep Duration and Impaired Glucose Metabolism', World Journal of Diabetes, 8(8), p. 397. doi: 10.4239/wjd.v8.i8.397.

Nuchalida (2015) Hubungan Lamanya Menderita Diabetes Mellitus Tipe 2 dengan Penurunan Fungsi Kognitif. Nuraisyah, F. (2017) 'Faktor Risiko 
Diabetaes Mellitus Tipe 2', Jurnal

Kebidanan dan Keperawatan Aisyiyah, 13(2), pp. 120-127. doi: 10.31101/jkk.395

Nurmaguphita, D. and Sugiyanto (2018) 'Gambaran Distress pad penderita Diabetes Mellitus', Jurnal Keperawatan, 6(6), pp. 76-82.

Palimbunga, T. M., Rataq, B. T. and Kaunang, W. P. J. (2017) 'FaktorFaktor yang berhubungan dengan Kejadian Diabetes Melitus Tipe 2 di RSU GMIM Pancaran Kasih Manado', FKM Unsrat Manado, 9(3), pp. 1-11.

Permana, Y. I. (2017) Hubungan antara Lama Sakit dengan Tingkat Distress pada Pasien Diabetes Melitus di Rumah Sakit Islam Surakarta.

Prabowo, A. and Hastuti, W. (2015) 'Hubungan Pendidikan dan Dukungan Keluarga dengan Kepatuhan Diit pada Penderita Diabetes Mellitus di Wilayah Puskesmas', Jurnal Keperawatan GSH, 1, 4(2), pp. 1-12.

Prasetyani, D. and Apriani, E. (2017) 'Karakteristik Pasien Diabetes Melitus Tipe II di Puskesmas Cilacap Tengah 1 dan 2', Bidan Prada: Jurnal Publikasi Kebidanan Akbid YLPP Purwokerto, pp. 1-8.

Rahayu, K., Saraswati, L. and Setyawan, H. (2018) 'Faktor-Faktor yang Berhubungan Dengan Kadar Gula Darah pada Penderita Diabetes Melitus Tipe 2 (Studi Di Wilayah Kerja Puskesmas Kedungmundu Kot Semarang)', Jurnal Kesehatan Masyarakat, 6(2), pp. 19-28.

Restada, E. J. (2016) Hubungan Lama Menderita dan Komplikasi Diabetes Melitus denga Kualitas Hidup pada Penderita Diabetes Melitus di Wilayah Puskesmas Gatak Sukoharjo.

Indonesian Ministry of Health (2014) 'Situasi dan Analisis Diabetes'.

RISKESDAS (2018) 'Hasil Utama Riset Kesehatan Dasar 2018', Kementrian
Kesehatan Republik Indonesia, 1(1), pp. 1-200. doi: 1 Desember 2013.

Rudi, A. and Kwureh, H. N. (2017) 'Faktor Risiko yang Mempengaruhi Kadar Gula Darah Puasa pada Pengguna Layanan Laboratorium', 3(2), 3339.'doi: $10.33485 /$ jiik-wk.v3i2.21

Seghieri, C. et al. (2016) 'Gender Differences in The Relationship between Diabetes Process of Care Indicators and Cardiovascular Outcomes', European Journal of Public Health, 26(2), pp. 219-224. doi: 10.1093/eurpub/ckv159.

Sidiq, R. and Nurleli (2015) 'Hubungan Lama Menderita Penyakit dengan Pengetahuan Perawatan Kulit dan Kaki pada Pasien Diabetes Melitus Tipe 2 di Ruang Mamplam Rumah Sakit Umum Daerah dr. Zaenoel Abidin Banda Aceh', Idea Nursing Journal, 6(2), pp. 30-35.

Siwiutami, F. (2017) Gambaran Kualitas Hidup Pada Penyandang Diabetes Melitus di Wilayah Puskesmas Purwosari Surakarta.

Surabaya, D. K. K. (2018) Laporan Program Pelayanan Kesehatan Penderita Hipertensi dan Diabetes Melitus Bulan Januari - September 2018.

Susanti, E. N. F. (2019) Gambaran Faktor Risiko Terjadinya Diabetes Melitus Pada Penderita Diabetes Melitus Tipe 2.

Timur, D. K. P. J. (2016) 'Data dan Informasi Kesehatan Provinsi Jawa Timur', Dinkes Provinsi Lampung.

Tsalissavrina, I. et al. (2018) 'Hubungan Lama Terdiagnosa Diabetes dan kadar GLukosa Darah dengan FUngsi Kognitif Penderita Diabetes Tipe 2 di Jawa Timur', Jurnal AcTion: Aceh Nutrition Journal, 3(1), pp. 28-33. doi: 10.30867/action.v3i1.9.

Wahyuni, Y., Nursiswati and Anna, A. (2014) 'Kualitas Hidup berdasarkan Karekteristik Pasien Diabetes 
Melitus Tipe 2', Jurnal Keperawatan Padjadjaran, 2(April), pp. 25-34. doi: 10.24198/jkp.v2i1.79.

Wardani, A. K. and Isfandiari, M. A. (2014) 'Hubungan DUkungan Keluarga dan Pengedalian Kadar Gula Darah dengan Gejala Komplikasi Mikrovskuler', Jurnal Berkala Epidemiologi, 2, pp. 1-12.

Wardiah and Emilia, E. (2018) 'Faktor Risiko Diabetes Melitus pada Wanita Usia Reproduktif di Wilayah Kerja Puskesmas Langsa Lama Kota Langsa, Aceh', Jurnal Kesehatan Global, 1(3), pp. 119126. doi: $10.33085 / j k g . v 1 i 3.3975$.

WHO (2016) 'Global Report on Diabetes'. WHO (2018) WHO Health Statistic: Monitoring Health for the SDGs, Sustainable Development Goals.

Winta, A. E., Setiyorini, E. and Wulandari, N. A. (2018) 'Hubungan Kadar Gula Darah dengan Tekanan Darah pada Lansia Penderita Diabetes Tipe 2', Ners dan Kebidanan, 5(2), pp. 163-71. doi: 10.26699/jnk.v5i2.ART.p163.

$\mathrm{Wu}, \quad \mathrm{Y}$. et al. (2014) 'Risk Factors Contributing to Type 2 Diabetes and Recent Advances in The Treatment and Prevention.', International Journal of Medical Sciences, 11(11), pp. 1185-200. doi: 10.7150/ijms.10001.

Yosmar, R., Almasdy, D. and Rahma, F. (2018) 'Survei Risiko Penykit Dibetes Melitus terhdap Masyarakat Kota Padang', Jurnal Sains Farmasi dan Klinis, 5(2), pp. 134-141. doi: 10.25077/jsfk.5.2.134-141.2018.

Yuliani, F., Oenzil, F. and Iryani, D. (2015) 'Hubungan Berbagai Faktor Risiko Terhadap Kejadian Penyakit Jantung Koroner Pada Penderita Diabetes Melitus Tipe 2', Jurnal Kesehatan Andalas, 3(1), pp. 3740.

Zahari, A. Z., Yunivita, V. and Martha, J. W. (2017) 'Knowledge, Attitude and Practice of Diabetes Mellitus Type 2 Patients towards Compliance to Treatment in Pusat Kesehatan Masyarakat', Althea Medical Journal, 3(3), pp. 416-420. doi: 10.15850/amj.v3n3.871. 